tosus, and review of literature. New England Journal of Medicine, 263, 625.

RowE, P.B. (1963) Disseminated lupus erythematosus with Sydenham's chorea: report of a case with a review of literature. Medical Journal of Australia, 2, 586.

Seminario, C. \& Pressano, J. (1930) Cuarto casos clinicos de lupus eritematoso agudo. Semaine médicale, 2, 721.
TAY, C.H. (1971) Neurological involvement in systemic lupus erythematosus. Singapore Medical Journal, 12, 18.

Willoughby, E.O., Cardon, L. \& Rubnitz, M.E. (1964) Clinopathologic conference; psychotic episodes, meningitis and chest pain. Postgraduate Medical Journal, 35, 318.

Postgraduate Medical Journal (March 1974) 50, 166-171.

\title{
Oxymetholone in aplastic anaemia
}

\author{
M. A. MIR \\ M.B., B.S., D.C.H., M.R.C.P. \\ I. W. Delamore \\ M.B., Ph.D., F.R.C.P.(Ed.), M.R.C.PATH. \\ University Department of Clinical Haematology, Manchester Royal Infirmary, \\ Oxford Road, Manchester, M13 9WL
}

\begin{abstract}
Summary
Thirty-one patients with aplastic anaemia were treated with oxymetholone. Twenty-eight patients lived beyond 2 months and of these eleven patients showed clinical and haematological improvement. Ten of these had some active erythropoietic areas as shown by bone marrow biopsies and by the presence of an elevated reticulocyte count in the peripheral blood. Two patients who responded in spite of a markedly hypoplastic marrow and reticulocytopenia became oxymetholone dependent and relapsed when the drug was withdrawn. They failed to respond a second time when oxymetholone was re-introduced. Side effects were frequent. These were mostly tolerable and reversible on reduction of the dose but three patients died of acute myeloblastic leukaemia and in three others the drug had to be withdrawn.
\end{abstract}

DURING recent years androgenic hormones have been used extensively in aplastic anaemia (Shahidi and Diamond, 1961; Sanchez-Medal et al., 1964; Reynafarje and Faura, 1967; Daiber et al., 1970). Promising reports have appeared in favour of oxymetholone which is an oral androgen. SanchezMedal et al. (1969) claimed a remission rate of $70 \%$ in patients with aplastic anaemia who lived longer than 2 months and thus received an adequate trial with oxymetholone. Similar results have been reported by Allen et al. (1968) and by Silink and Firkin (1968).

We present here our experience with oxymetholone on thirty-one patients with aplastic anaemia.
Patients and methods

Thirty-one patients were treated. All had pancyto penia and a marrow with reduced cellularity at some stage on serial trephine biopsies. In nine patients aplastic anaemia was considered to be drug-induced (Table 1). All other causes of anaemia were excluded by a careful clinical assessment and by haematological investigations. Patients with primary disease affecting the bone marrow by infiltration or by replacement of active haemopoietic tissue were excluded.

Haematological investigation and ferrokinetic studies were performed by standard methods (Dacie and Lewis, 1968). All patients had a sternal marrow aspiration and a trephine biopsy on the iliac crest. Both these procedures were repeated on seventeen patients to define the extent of aplasia and to assess the response to therapy. Sixteen patients died and autopsies were performed on nine. In these patients sections from the pelvis and from the vertebral column were examined histologically to get an overall picture of the marrow cellularity. Marrow cellularity was divided into the following sub-headings according to the observations made on the trephine sections:

(a) Marked hypoplasia. The trephine sections showed an occasional collection of lymphocytes or reticulum cells among the fatty cells. There was a $\stackrel{?}{+}$ severe depression of the erythro-myeloid elements and a complete absence of megakaryocytes.

(b) Moderate hypoplasia. A marked reduction of the overall cellularity but an occasional island of 
normal erythroid or myeloid series was seen. No megakaryocytes were found.

(c) Mild hypoplasia. A general reduction in the cellularity but scattered among areas of complete aplasia were some foci of normal marrow elements. There were no megakaryocytes.

(d) Patchy hypoplasia with hyperplasia. Two patients (cases 9 and 27) were found to have foci of increased cellularity with some patches devoid of cells. Megakaryocytes were severely reduced or absent.

Oxymetholone was administered orally in a dosage of $3-5 \mathrm{mg} / \mathrm{kg}$ a day to all the thirty-one patients. This dose was reduced to $1.5-2 \mathrm{mg} / \mathrm{kg} /$ day in the surviving patients after 2 months. More than half the patients were receiving prednisolone before the therapy with oxymetholone. Corticosteroids were gradually tailed off although some patients were maintained on $10 \mathrm{mg}$ of prednisolone a day.

\section{Results}

Of the thirty-one patients treated with oxymetholone, three died within the first 4 weeks. Since treatment with oxymetholone takes about 2 months to produce a worthwhile therapeutic effect (Allen et al., 1968; Sanchez-Medal et al., 1969), these three patients were excluded from the final consideration.
Table 1 shows the initial clinical and haematological data of the remaining twenty-eight patients. There were thirteen males and fifteen female patients. The average age of the whole group was 45 years. The shortest duration of symptoms before the first presentation was one week (case 19) and the longest 2 years and 8 months (case 2). The average duration of symptoms before the first medical attendance was 6.6 months. The presentation of symptoms tended to be more acute in patients where a toxic agent could be incriminated. The idiopathic cases on the other hand had a more insidious onset.

\section{Response to oxymetholone}

Complete remission was considered to have occurred if all the peripheral blood indices returned to normal and if the marrow showed evidence of regeneration on subsequent examinations. There was only one instance of complete remission (case 19) when the peripheral blood picture returned to normal in 7 months from the onset of treatment with oxymetholone. The bone marrow which was markedly hypoplastic before treatment showed erythromyeloid areas of regeneration on subsequent examination. However, the aplastic state reappeared

TABLE 1. Clinical and haematological details of twenty-eight patients on first admission

\begin{tabular}{|c|c|c|c|c|c|c|c|c|c|}
\hline No. & Name & $\begin{array}{c}\text { Age } \\
\text { (years) }\end{array}$ & Sex & $\begin{array}{c}\text { Duration } \\
\text { of } \\
\text { symptoms* }\end{array}$ & $\begin{array}{c}\mathrm{Hb} \\
\left(\mathrm{g}^{\circ} \%\right)\end{array}$ & $\begin{array}{c}\text { WCC } \\
10^{3} / \mathrm{mm}^{3}\end{array}$ & $\begin{array}{l}\text { Platelets } \\
10^{3} / \mathrm{mm}^{3}\end{array}$ & $\begin{array}{c}\text { Reticulocytes } \\
\%\end{array}$ & Marrow \\
\hline 1 & RF & 28 & $M$ & 2 & $8 \cdot 1$ & $2 \cdot 5$ & 25 & n.d. & a \\
\hline 2 & JB & 21 & $\mathbf{F}$ & 32 & 7 & 3 & 32 & 0.5 & $\mathbf{a}$ \\
\hline 3 & CS & 75 & $F$ & 12 & $4 \cdot 7$ & $2 \cdot 7$ & 33 & $3 \cdot 6$ & b \\
\hline 4 & HB & 16 & $\mathbf{F}$ & 16 & $3 \cdot 2$ & $2 \cdot 5$ & 14 & $2 \cdot 2$ & c \\
\hline 5 & RH & 42 & $\mathbf{M}$ & 6 & $4 \cdot 7$ & 2 & 10 & n.d. & $\mathbf{a}$ \\
\hline 6 & WG & 52 & $\mathbf{M}$ & 2 & $6 \cdot 5$ & $2 \cdot 6$ & 50 & 0.8 & b \\
\hline $7 \dagger$ & PB & 18 & F & 1 & 13 & $3 \cdot 2$ & $9 \cdot 4$ & 0.5 & b \\
\hline $8 \dagger$ & EM & 72 & F & 2 & $5 \cdot 8$ & 2 & 22 & $2 \cdot 8$ & b \\
\hline $9+$ & JG & 52 & $\mathbf{M}$ & 1 & 8 & $3 \cdot 4$ & 27 & none & d \\
\hline 10 & RM & 30 & $\mathbf{M}$ & 2 & 5 & $2 \cdot 8$ & 10 & 0.8 & b \\
\hline 11 & DC & 18 & $\mathbf{M}$ & 1 & $6 \cdot 5$ & $4 \cdot 6$ & 9 & 0.5 & b \\
\hline $12 \dagger$ & HK & 68 & $F$ & 12 & $9 \cdot 5$ & $8 \cdot 8$ & 76 & 8 & c \\
\hline $13 \dagger$ & ND & 59 & $\mathbf{F}$ & 12 & $7 \cdot 9$ & $2 \cdot 2$ & 8 & 0.5 & a \\
\hline 14 & NJ & 39 & F & incidental & $7 \cdot 2$ & $1 \cdot 4$ & 148 & $2 \cdot 3$ & c \\
\hline $15 \dagger$ & LK & 58 & F & 2 & 9 & 2 & 7 & $0 \cdot 8$ & $\mathbf{a}$ \\
\hline 16 & CF & 26 & F & 0.5 & $6 \cdot 2$ & 2 & 9 & $0 \cdot 2$ & a \\
\hline 17 & AS & 69 & $\mathbf{F}$ & 5 & $8 \cdot 6$ & 3 & 79 & n.d. & $\mathbf{a}$ \\
\hline 18 & GG & 48 & $\mathbf{M}$ & 3 & 10 & $3 \cdot 7$ & 49 & 0.8 & b \\
\hline 19 & $\mathbf{A M}$ & 38 & $\mathbf{M}$ & 0.25 & $6 \cdot 2$ & 3 & 6 & none & $\mathbf{a}$ \\
\hline $20 \dagger$ & WH & 68 & $\mathbf{M}$ & incidental & $7 \cdot 1$ & $2 \cdot 2$ & 11 & 0.2 & b \\
\hline 21 & $\mathrm{JC}$ & 67 & $F$ & 1 & 6.9 & 3.8 & 8 & n.d. & b \\
\hline $22 \dagger$ & LS & 55 & F & 9 & 10.9 & $4 \cdot 6$ & 7 & 0.5 & b \\
\hline 23 & DF & 4 & $\mathbf{M}$ & 1 & 3 & $8 \cdot 4$ & 8 & 3 & b \\
\hline 24 & RD & 57 & $\mathbf{M}$ & 24 & 7 & 4 & 70 & 4.9 & b \\
\hline 25 & BS & 39 & $F$ & 6 & $6 \cdot 1$ & 3.9 & 10 & $1 \cdot 8$ & b \\
\hline $26 \dagger$ & WT & 60 & $\mathbf{M}$ & 1 & 8 & $3 \cdot 1$ & 31 & $3 \cdot 7$ & b \\
\hline 27 & DH & 48 & F & 24 & $5 \cdot 4$ & 3 & 6 & n.d. & d \\
\hline 28 & $\mathrm{AE}$ & 18 & $\mathbf{M}$ & unknown & $10 \cdot 2$ & $2 \cdot 8$ & 11 & n.d. & b \\
\hline
\end{tabular}

$a=$ marked hypoplasia $; b=$ moderate hypoplasia $;=$ mild hypoplasia; $d=$ patchy hypoplasia with hyperplasia; .d. $=$ not done.

* Duration of symptoms in months before first medical attendance.

$\dagger$ Secondary to a toxic agent. 
when the therapy was discontinued as shown in Fig. 1. Treatment with oxymetholone was restarted and the patient was also put on prednisolone but he failed to improve and died from septicaemia and generalized haemorrhage. Ten other patients showed a partial response with an appreciable improvement in

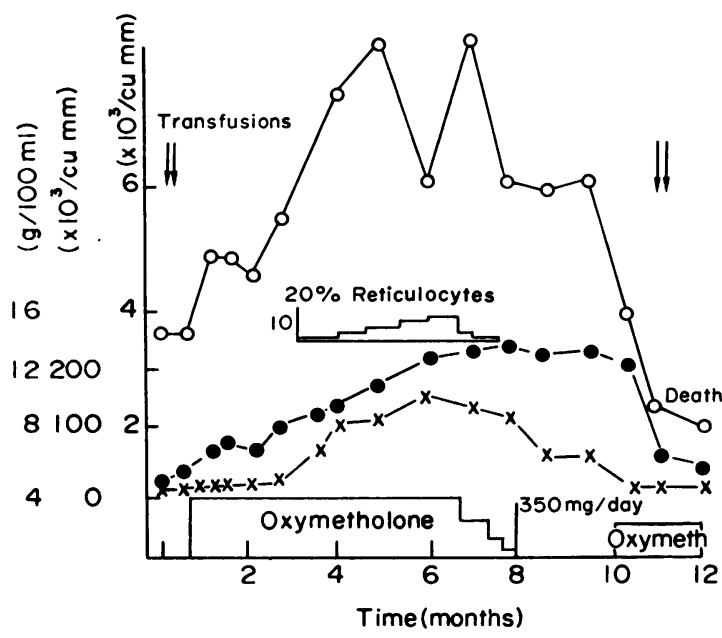

Fig. 1. Haematological response to oxymetholone in a patient (case 19) with aplastic anaemia. The marrow aplasia relapsed fatally 2 months after cessation of the oxymetholone therapy. $\odot=\mathrm{Hb}(\mathrm{g} / 100 \mathrm{ml}) ; \times=$ platelets $\left(\times 10^{3} / \mathrm{mm}^{3}\right) ; \bigcirc=W C C\left(\times 10^{3} / \mathrm{mm}^{3}\right)$. the haemoglobin $(\mathrm{Hb})$ and some increase in the $\stackrel{\mathbb{Q}}{\circ}$ white cell count (WCC). Platelets increased very $c$. slowly and counts above $100,000 / \mathrm{mm}^{3}$ were obtained $\vec{F}$ only in three instances (Table 2). The trephine $\stackrel{\stackrel{S}{+}}{+}$ sections showed some improvement in seven patients followed over 3 years (Table 2). Case 27, however, showed a change to a marked hypoplasia on repeated trephine biopsies in spite of a clinical and haemato- $\triangle$ logical improvement. A favourable response was signalled by stabilization of the $\mathrm{Hb}$ level around 8-9 $\mathrm{g} \%$ and an increase in the reticulocyte percentage (Table 2, Fig. 1). There was a slow increase in the WCC and a further improvement in the $\mathrm{Hb}$ con- o centration during the 6-12 weeks from the onset of therapy. Another favourable feature which fore- 3 shadowed remission in some cases was a relative 7 increase in polymorphs. The absolute neutrophil in count increased very slowly and in five cases re- $\stackrel{\infty}{-}$ mained between 2000 and $3000 / \mathrm{mm}^{3}$. A gradual $\vec{\sigma}$ proliferation of the haemopoietic tissue occurred in seven patients followed over 3 years.

Island of active erythropoiesis on the trephine sections and some reticulocytes in the peripheral blood usually heralded a good prognosis. Of the eleven patients who responded, six had a reticulocyte count of more than $2 \%$ (Table 2) and tea $\vec{\varphi}$ patients had some erythropoietic areas on the tre phine sections. Out of the whole group of twent eight patients treated for more than 2 months, onfy two patients (cases 14 and 26) showed no response

TABLE 2. Pre- and post-treatment haematological data of patients responding to oxymetholone

\begin{tabular}{|c|c|c|c|c|c|c|c|}
\hline $\begin{array}{l}\text { Case } \\
\text { No. }\end{array}$ & $\begin{array}{r}\text { WC } \\
\left(\times 10^{3}\right)\end{array}$ & $\begin{array}{l}\mathrm{C} \\
\left.\mathrm{nm}^{3}\right)\end{array}$ & $\begin{array}{c}\text { Platelets } \\
\left(\times 10^{3} / \mathrm{mm}^{3}\right)\end{array}$ & $\underset{(\mathrm{gb} / \mathrm{o})}{\mathrm{Hb}}$ & $\begin{array}{c}\text { Reticulocytes } \\
(\%)\end{array}$ & Marrow & Remarks \\
\hline 3 & $\begin{array}{l}\text { before } \\
\text { after }\end{array}$ & $\begin{array}{l}2 \cdot 7 \\
5 \cdot 1\end{array}$ & $\begin{array}{l}33 \\
72\end{array}$ & $\begin{array}{r}4 \cdot 7 \\
11 \cdot 9\end{array}$ & $\begin{array}{r}3 \cdot 6 \\
60 \cdot 0\end{array}$ & $\begin{array}{l}b^{*} \\
c^{*}\end{array}$ & Alive -3 years \\
\hline 4 & $\begin{array}{l}\text { before } \\
\text { after }\end{array}$ & $\begin{array}{l}2 \cdot 5 \\
4 \cdot 2\end{array}$ & $\begin{array}{l}14 \\
25\end{array}$ & $\begin{array}{r}3 \cdot 2 \\
12 \cdot 2\end{array}$ & $\begin{array}{l}2 \cdot 2 \\
7 \cdot 0\end{array}$ & $\begin{array}{l}\text { c } \\
\text { c }\end{array}$ & $\begin{array}{l}\text { Needs occasional } \\
\text { blood transfusion }\end{array}$ \\
\hline 6 & $\begin{array}{l}\text { before } \\
\text { after }\end{array}$ & $\begin{array}{l}2 \cdot 6 \\
9 \cdot 2\end{array}$ & $\begin{array}{l}50 \\
40\end{array}$ & $\begin{array}{r}6 \cdot 5 \\
13 \cdot 6\end{array}$ & $\begin{array}{l}0 \cdot 8 \\
3 \cdot 0\end{array}$ & $\begin{array}{l}\text { b } \\
\text { c }\end{array}$ & Alive -4 years \\
\hline 8 & $\begin{array}{l}\text { before } \\
\text { after }\end{array}$ & $\begin{array}{l}2 \cdot 0 \\
7 \cdot 7\end{array}$ & $\begin{array}{r}22 \\
124\end{array}$ & $\begin{array}{r}5 \cdot 8 \\
15 \cdot 6\end{array}$ & $\begin{array}{l}2 \cdot 8 \\
5 \cdot 0\end{array}$ & $\begin{array}{l}\mathrm{b} \\
\mathrm{c}\end{array}$ & Alive -3 years \\
\hline 9 & $\begin{array}{l}\text { before } \\
\text { after }\end{array}$ & $\begin{array}{l}3 \cdot 4 \\
5 \cdot 0\end{array}$ & $\begin{array}{l}27 \\
96\end{array}$ & $\begin{array}{r}8 \cdot 0 \\
12 \cdot 7\end{array}$ & $\begin{array}{r}\text { none } \\
4 \cdot 2\end{array}$ & $\begin{array}{l}d^{*} \\
d\end{array}$ & Alive -5 months \\
\hline 10 & $\begin{array}{l}\text { before } \\
\text { after }\end{array}$ & $\begin{array}{l}2 \cdot 8 \\
3 \cdot 5\end{array}$ & $\begin{array}{l}10 \\
88\end{array}$ & $\begin{array}{r}5 \cdot 0 \\
13 \cdot 1\end{array}$ & $\begin{array}{l}0 \cdot 8 \\
3 \cdot 6\end{array}$ & $\begin{array}{l}\mathrm{b} \\
\mathrm{c}\end{array}$ & Alive -4 years \\
\hline 12 & $\begin{array}{l}\text { before } \\
\text { after }\end{array}$ & $\begin{array}{r}8 \cdot 8 \\
132 \cdot 0\end{array}$ & $\begin{array}{l}76 \\
32\end{array}$ & $\begin{array}{l}9 \cdot 5 \\
5 \cdot 8\end{array}$ & $\begin{array}{l}8 \cdot 0 \\
4 \cdot 0\end{array}$ & $\begin{array}{l}c \\
\text { d }\end{array}$ & $\begin{array}{l}\text { Developed } \\
\text { leukaemia }\end{array}$ \\
\hline 19 & $\begin{array}{l}\text { before } \\
\text { after }\end{array}$ & $\begin{array}{l}3 \cdot 0 \\
6 \cdot 1\end{array}$ & $\begin{array}{r}6 \\
148\end{array}$ & $\begin{array}{r}6 \cdot 2 \\
13 \cdot 3\end{array}$ & $\begin{array}{c}\text { none } \\
14 \cdot 0\end{array}$ & $\begin{array}{l}a^{*} \\
d\end{array}$ & See Fig. 1 \\
\hline 23 & $\begin{array}{l}\text { before } \\
\text { after }\end{array}$ & $\begin{array}{l}8 \cdot 4 \\
5 \cdot 0\end{array}$ & $\begin{array}{r}8 \\
30\end{array}$ & $\begin{array}{r}3.0 \\
12.6\end{array}$ & $\begin{array}{l}3 \cdot 0 \\
6 \cdot 0\end{array}$ & $\begin{array}{l}\text { b } \\
\text { c }\end{array}$ & Alive -3 years \\
\hline 24 & $\begin{array}{l}\text { before } \\
\text { after }\end{array}$ & $\begin{array}{l}4 \cdot 0 \\
4.9\end{array}$ & $\begin{array}{r}70 \\
130\end{array}$ & $\begin{array}{r}7 \cdot 0 \\
10 \cdot 0\end{array}$ & $\begin{array}{l}4 \cdot 9 \\
5 \cdot 0\end{array}$ & $\begin{array}{l}\mathrm{b} \\
\mathrm{c}\end{array}$ & $\begin{array}{l}\text { Lost to follow up } \\
\text { after } 18 \text { months }\end{array}$ \\
\hline 27 & $\begin{array}{l}\text { before } \\
\text { after }\end{array}$ & $\begin{array}{l}3 \cdot 0 \\
5.9\end{array}$ & $\begin{array}{r}6 \\
76\end{array}$ & $\begin{array}{r}5 \cdot 4 \\
14 \cdot 7\end{array}$ & $\begin{array}{l}\text { n.d. } \\
2 \cdot 1\end{array}$ & $\begin{array}{l}d \\
a\end{array}$ & Alive -3 years \\
\hline
\end{tabular}


in spite of an initial reticulocyte count of more than $2 \%$, but both these patients are still alive with the aid of monthly blood transfusions. One patient with marked hypoplasia (case 17) responded slightly to oxymetholone but her therapy was discontinued because of the side effects (diarrhoea, acne, deepening of the voice, etc.). This withdrawal of oxymetholone was followed by a severe pancytopenia which proved refractory to a second course of oxymetholone and she died of septicaemia. These two patients (cases 17 and 19) showed oxymetholone dependence and relapsed fatally on withdrawal of the drug. It is interesting to note that these were the only two patients who responded to oxymetholone in spite of a markedly hypoplastic marrow and a peripheral reticulocytopenia.

\section{Mortality}

Sixteen patients died over the period of 4 years; three during the first month, two in the next 6 months, eight in the subsequent 16 months, and two during the next 2 years. The death rate decreased as the duration of therapy increased. The overall remission rate in the twenty-eight patients treated for more than 2 months was $39 \cdot 2 \%$.

\section{Factors influencing mortality}

A low $\mathrm{Hb}$ concentration did not appear to increase the risk of death (Table 3). This finding was not surprising as the patients with a low $\mathrm{Hb}$. level were well supported with frequent blood transfusions. A neutropenia of less than $500 / \mathrm{mm}^{3}$ was very unfavourable as eight patients out of twelve with such meagre counts died. This mortality rate was significantly higher $(P<0.05)$ than in the neutropenic group with an absolute neutrophil count between 500 and $2000 / \mathrm{mm}^{3}$. Thrombocytopenia of less than $10,000 / \mathrm{mm}^{3}$ also carried a bad prognosis as five out of the ten patients died. The initial higher $\mathrm{Hb}$ level did not influence the subsequent downhill course in patients who had a markedly hypoplastic marrow. Whatever the other haematological values, patients with marked hypoplasia of the marrow as defined here had a very grave outcome with a death rate of $88.8 \%$ (Table 3 ). On the other hand patients with a moderate hypoplasia had a very low mortality rate of $18.1 \%$. The difference between the death rates in these two groups was statistically significant $(P<$ 0.005).

\section{Side effects of oxymetholone}

High doses of oxymetholone given initially were well tolerated by most patients. Acne, deepening of the voice and a significant increase in the facial hair were the main complaints in four female patients (cases 2, 15, 17, and 25). One patient (case 17) also developed intractable nocturnal diarrhoea necessitating withdrawal of oxymetholone. Acne proved to be very disfiguring in case 25 . Sickness and diarrhoea were experienced by one more patient (case 22) but these symptoms subsided on reduction of the dosage to $150 \mathrm{mg}$ a day. Significant retention of fluid occurred in three patients (cases 17, 21 and 22) but all of these had pre-existing heart disease. Mild fluid retention developed in eight patients with an increase in weight. Six of these patients also complained of troublesome night cramps. Four patients developed mild jaundice with an impairment of the hepatic function tests (cases 7, 14, 20 and 21). In one of these (case 7) the jaundice became deeper with a serum glutamic-oxaloacetic (SGOT) level of $700 \mathrm{units} / \mathrm{ml}$ and serum glutamic-pyruvic transaminase (SGPT) level of 1500 units $/ \mathrm{ml}$ (normal less than 30 units $/ \mathrm{ml}$ ). Abnormal values returned to normal in the surviving patients (cases 7 and 14) following cessation of oxymetholone therapy. Case 21 has not been under observation long enough to draw any conclusions. Three patients (cases 11, 12 and 20) developed

TABle 3. Prognostic significance of haematological data

\begin{tabular}{|c|c|c|c|}
\hline & No. of patients & Deaths & $\begin{array}{c}\text { Significance } \\
(P)\end{array}$ \\
\hline $\begin{array}{l}\text { Haemoglobin }(g \%) \\
\text { Less than } 5 \\
\text { Between } 5 \text { and } 8 \\
\text { Between } 8 \text { and } 11 \cdot 7\end{array}$ & $\begin{array}{r}4 \\
15 \\
8\end{array}$ & $\begin{array}{l}1(25 \%) \\
6(40 \%) \\
5(62 \cdot 5 \%)\end{array}$ & $\begin{array}{l}\text { n.s. } \\
\text { n.s. }\end{array}$ \\
\hline $\begin{array}{l}\text { Neutrophils } / \mathrm{mm}^{3} \\
\text { Less than } 500 \\
\text { Between } 500 \text { and } 2000\end{array}$ & $\begin{array}{r}12 \\
8\end{array}$ & $\begin{array}{l}8(66 \cdot 6 \%) \\
1(12 \cdot 5 \%)\end{array}$ & $<0.05$ \\
\hline $\begin{array}{l}\text { Platelets/cu.mm } \\
\text { Less than } 10,000 \\
\text { Between } 10,000 \text { and } 50,000\end{array}$ & $\begin{array}{l}10 \\
13\end{array}$ & $\begin{array}{l}5(50 \%) \\
4(30.7 \%)\end{array}$ & n.s. \\
\hline $\begin{array}{l}\text { Marrow } \\
\text { Marked hypoplasia } \\
\text { Moderate hypoplasia }\end{array}$ & $\begin{array}{r}9 \\
14\end{array}$ & $\begin{array}{l}8(88 \cdot 8 \%) \\
2(14 \cdot 2 \%)\end{array}$ & $<0.005$ \\
\hline
\end{tabular}


leukaemia whilst on oxymetholone. This rapid transformation from hypocellular marrow to sheets of blast cells may be related to a myelostimulatory effect of oxymetholone. The case records of these patients have been reported elsewhere (Delamore and Geary, 1971).

\section{Discussion}

Oxymetholone produced an effective remission in eleven of the twenty-eight patients with aplastic anaemia treated for periods longer than 2 months. Some workers have claimed remission in a higher proportion of cases (Sanchez-Medal et al., 1969; Allen et al., 1968; Silink and Firkin, 1968). It is difficult to compare one series with the other in a disease where fundamental differences occur in the diagnostic criteria and in the standards set for remission by various workers. There is no entirely satisfactory definition of aplastic anaemia (Wintrobe, 1967; Mohler and Leavell, 1958). These difficulties are compounded by a tendency of this disease to spontaneous remissions and relapses (Scott, Cartwright and Wintrobe, 1959; Bomford and Rhoads, 1941) which makes evaluation of any therapy very difficult. However, the eleven patients here showed increasing reticulocytosis with an increase in the $\mathrm{Hb}$ concentration while on oxymetholone. A previous review of our patients before the advent of oxymetholone showed only a $25 \%$ remission rate (Israel and Wilkinson, 1961), and it would appear that oxymetholone has significantly improved the survival rate.

Androgenic steroids have long been considered to possess some stimulatory effect on the bone marrow (Pfeiffer and Gardner, 1938; McCullagh and Jones, 1942; Kennedy and Gilbertson, 1956) but the precise mechanism of this stimulation is uncertain. Patients with aplastic anaemia have a prolonged plasma iron clearance and a low red-cell iron utilization (Silink and Firkin, 1968; McCredie, 1969). These workers found that the low values return to normal following treatment with oxymetholone. Ferrokinetic studies performed on three of our patients confirmed the presence of a subnormal plasma iron clearance and a low red-cell utilization. However, a normal plasma iron turnover in one patient on oxymetholone therapy (case 7) was unaccompanied by clinical or haematological recovery. There was an excessive deposition of iron in the marrow reticulum cells and erythroblasts without any effective erythropoiesis.

Alexanian, Nadell and Alfrey (1972) showed a five-fold increase in the urinary erythropoietin excretion following the administration of oxymetholone but haematological improvement occurred only in cases who had effective erythropoietic areas demonstrated by the marrow cellularity and by pelvic uptake of the ${ }^{59} \mathrm{Fe}$. In this study, ten out of the $\stackrel{\Phi}{\mathscr{Q}}$ eleven patients who responded had some active $c$. erythropoietic areas on serial marrow biopsies and $\overrightarrow{\vec{F}}$ six of these had a peripheral reticulocyte count of $\stackrel{\text { ? }}{\rightarrow}$ more than $2 \%$ (Table 2 ). The reticulocyte count $\frac{}{C}$ increased with the clinical improvement and the 흠 marrow showed a gradual cellular proliferation. $\frac{5}{\square}$ This regeneration proceeded unexpectedly to the $\stackrel{\overparen{Q}}{\varrho}$ formation of sheets of blast cells in three patients who died with leukaemia. The major site of action of $\vec{A}$ androgenic steroids appears to be in the bone marrow. The results of other workers support this $\vec{\omega}$ conclusion (Reynafarje and Faura, 1967; Jepson and Lowenstein, 1967).

In one patient (case 27) the initial increased cellu- 3 . larity regressed and the subsequent trephine sections if showed a marked hypoplasia in spite of an adequate $\mathcal{O}_{\infty}$ clinical and haematological response. The pretreat $\stackrel{\infty}{\rightarrow}$ ment hypercellularity probably represented clones of $\overrightarrow{\vec{\sigma}}$ ineffective erythropoietic areas which regressed with o

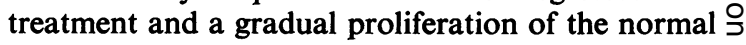
areas elsewhere ensued to produce the haemato- $\vec{r}$ logical remission. It is also possible that misleading biopsies were obtained although the trephine sections were taken from both iliac crests.

The presence of cellular foci did not appear influence the prognosis in patients studied by Lew $P$ (1965). Vincent and de Gruchy (1967) found correlation between the initial haematological values and ultimate survival. Other workers (Bomford and $\overline{0}$ Rhoads, 1941 ; Mohler and Leavell, 1958) showed a better prognosis associated with the presence of $\frac{\otimes}{\circ}$ cellular foci in the marrow. Alexanian et al. (1972) concluded that patients with markedly depressed erythropoiesis derived no benefit from oxymetholone. In this study, patients with cellular areas on the trephine sections had a better prognosis and appeared more likely to respond to oxymetholone. Marked hypoplasia of the marrow and severe neutropenia $\left(<500 / \mathrm{mm}^{3}\right)$ carried a significantly adverse prognosis (Table 3 ). Four patients who died within $\delta$ the first 3 months showed a progressive fall in their absolute neutrophil count. The patients who re- 0 sponded to oxymetholone, on the other hand, showed a gradual increase in neutrophils. The platelet count $\frac{7}{2}$ remained low and did not provide any prognostic indication although patients with less than $10,000 / \%$ $\mathrm{mm}^{3}$ fared badly.

Some workers recommend withdrawal of oxy- N metholone when a patient has remained in remission for a few weeks. Relapses following such withdrawals have not been uncommon (Allen et al., 1968; Sanchez-Medal et al., 1969). However, seven out of $\stackrel{\oplus}{\oplus}$ the eight patients who relapsed responded to oxy- 0 metholone for the second time in the group studied

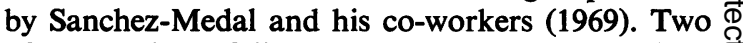
of our patients failed to respond to oxymetholone 
when re-introduced following a short withdrawal. Unlike the other patients who remitted on oxymetholone, these two patients had responded despite a markedly hypoplastic marrow. It would seem that if the patients with severe aplasia respond they may become wholly oxymetholone dependent and should be kept on the drug till there is a definite evidence of repopulation of the bone marrow. The withdrawal of therapy in such cases should be very slow and cautious.

In conclusion oxymetholone appears to be of definite value in patients with some erythropoietic areas in the marrow but the prognosis in patients with marked hypoplasia remains very grave.

\section{References}

Alexanian, R., Nadell, J. \& Alfrey, C. (1972) Oxymetholone treatment for the anaemia of bone marrow failure. Blood, 40, 353.

Allen, D.M., Fine, M.R., Necheles, T.F. \& DamasheK, W. (1968) Oxymetholone therapy in aplastic anaemia. Blood, $32,83$.

BOMFORD, R.R. \& RHOADS, C.P. (1941) Refractory anaemia. Quarterly Journal of Medicine, 10, 175.

DACIE, J.V. \& LewIS, S.M. (1968) Practical Haematology, 4th Edn. Churchill, London.

Daiber, A., Herve, L., Con, I. \& Donoso, A. (1970) Treatment of aplastic anaemia with Nandrolone Decanoate. Blood, 36, 748.

Delamore, I.W. \& Geary, C.G. (1971) Aplastic anaemia, acute myeloid leukaemia and oxymetholone. British Medical Journal, 2, 743.

ISRAEL, M.C.G. \& WiLkinson, J.F. (1961) Idiopathic aplastic anaemia. Lancet, i, 63.

JePSON, J.H. \& Lowenstein, L. (1967) The effect of testosterone, adrenal steroids and prolactin on erythropoiesis. Acta Haematologica, 38, 292.
KENNEDY, B.J. \& GiLbertSen, A.S. (1956) Increased erythropoiesis induced by androgenic hormones. Journal of Clinical Investigations, 35, 717.

LEWIS, S.M. (1965) Course and prognosis in aplastic anaemia. British Medical Journal, 1, 1027.

MCCREDIE, K.B. (1969) Oxymethalone in refractory anaemia. British Journal of Haematology, 17, 265.

MCCullagh, E.P. \& JoNEs, T.R. (1942) Effect of androgens on blood count of men. Journal of Clinical Endocrinology, 2, 243.

Mohler, D.N. \& Leavell, B.S. (1958) Aplastic anaemia: an analysis of 50 cases. Annals of Internal Medicine, 49, 326.

Pfeiffer, C.A. \& GARpNer, W.V. (1938) Skeletal changes and blood serum calcium levels in pigeons receiving oestrogens. Endocrinology, 23, 485.

REYNAFARJE, C. \& FAURA, J. (1967) Erythrokinetics in the treatment of aplastic anaemia with methandrostenolone. Archives of Internal Medicine, 120, 654.

Sanchez-Medal, L., Gomez-Leal, A., Duarte, L. \& Rico, M.G. (1969) Anabolic androgenic steroids in the treatment of acquired aplastic anaemia. Blood, 34, 283.

Sanchez-Medal, L., Pizzuto, J., Torre-Lopez, E. \& DERBEZ, R. (1964) Effect of oxymetholone in refractory anaemia. Archives of Internal Medicine, 113, 721.

Scott, J.L., Cartwright, G.E. \& Wintrobe, M.N. (1959) Acquired aplastic anaemia: an analysis of 39 cases and review of the pertinent literature. Medicine (Baltimore), 38, 119.

Shahidi, N.T. \& Diamond, L.K. (1961) Testosteroneinduced remission in aplastic anaemia of both acquired and congenital types. New England Journal of Medicine, 264, 953 .

Silink, S.J. \& Firkin, B.G. (1968) An analysis of hypoplastic anaemia with special reference to the use of oxymetholone ('Adroyd') in its therapy. Australian Annals of Medicine, 17, 224.

Vincent, P.C. \& De Gruchy, G.C. (1967) Complications and treatment of acquired aplastic anaemia. British Journal of Haematology, 13, 977.

Wintrobe, M.M. (1967) Clinical Haematology. 6th Edn. Kimpton, London.

\title{
The use of dicobalt edetate (Kelocyanor) in cyanide poisoning
}

\author{
B. HillmaN \\ M.B., Ch.B.(Bristol), M.R.C.P.(UK)
}

K. D. BARDHAN

D.Phil.(Oxon), M.B.B.S.(Madras), M.R.C.P.(UK)

\author{
J. T. B. BAIN \\ M.B.B.S.(Glasgow), D.R.C.O.G. \\ The Department of Medicine, The Royal Hospital, West Street, Sheffield, S1 3SR and \\ Imperial Chemical Industries Ltd, Billingham, Teesside, TS23 1LE
}

\section{Summary}

A case of accidental poisoning with sodium cyanide is reported. The patient was treated with a new antidote, dicobalt edetate (Kelocyanor). Blood levels of cyanide were shown to fall markedly.

\section{Introduction}

The standard treatment of cyanide poisoning has been the rapid intravenous administration of sodium nitrite followed by sodium thiosulphate (Chen, Rose and Clowse, 1934; Chen and Rose, 1952, 1956). 